\section{Looking for a context}

Rolle, anchoritic culture, and the Office of the Dead

\section{Denis Renevey}

The Expositio super noveml lectiones (hereafter Super novem lectiones) is Rolle's penultimate The nine Latin treation precte responses and hymns, the Office of the Dead, it is appropriate to define it as a liturgical commentary, even if that definition requires qualifications. One of the hallmarks of Rolle's pieces in general, and of Super novem lectiones in particular, is that they turn out to be other and more than what they usually set out to be, very much as a consequence of Rolle's personal engagement with, and appropriation f the texts that he scrutinises. Although unlike some of his previous Latin writings which pollo's persona as a fundamental cog for the development of mystical which place Rolle's pessona as a fudations and religious thoughts, Super novem lectiones nevertheless also shows Rolle firs aligning himself with the biblical characters, in this case Job, and then assuming their role in contemporary dress, which nevertheless allows autobiographical trait to surface. There is no denying that, as Rolle has embraced (and then displaced) the personae of Solomon and David in his commentaries of the books attributed to them, he endorses a similar role in this piece. But the biblical narrative depicting Job, Job, moving from showing Job fist as a man living in the word a ble a wealth of material possessions, to one experiencing a state of complete deprivation as a way of testing his spiritual stamina, has a resonance which would have appealed to the pious laity. This chapter considers the contexts which facilitated the Book of Job's transmission and access, in all or in part, to a broad readership. It then turns to the impact anchoritic culture may have had in the production of Rolle's work on this biblical book; thirdly, it looks at the fifteenth-century clericallay interface in York to provide a better understanding for the popularity of the Rollean piece in the fifteenth century.

\section{Context one: exegetical and liturgical contexts}

Gregory's Moralia in Job was an important hermeneutic compendium for medieval receptions of the content of the Book of Job. Gregory touches upon every verse of the Book and delivers a commentary in thirty-five books, with literal, moral and allegorical interpretations. The commentary form, which is set out a the start, becomes structurally less visible from book four onwards, and leaves room for a looser piece in the form of a theological treatise. The Moralin is replete with passages expressing longing for the contemplative life, a state which Gregory with passages expressing longing for the contemplative life, a state which Gregory
could only yearn for while he was serving as a nuncio in Constantinople at the time of composition in 579-85. The importance of the Moralia is attested by the fact that it is the sole source for the glosses on the Book of Job in the Glossa ordinaria, in contradistinction to other Biblical books which are articulated around the interpretations of different authoritative voices. According to Wasselynck, the compiler of the Glossa ordinaria prefor school - follows the scriptural method laid out by Gregory the Great in his Epistola missoria ad Leandrum, which precedes the preface to the Moralia. The popularity of the Glossa ordinaria among clerics certainly contributed to the wide dissemination of the story of Job as well as the orthodox exegesis that should be applied for its understanding.

Another account of Job received sustained attention in the medieval period. The apocryphal Testament of $70 b$ embellishes the Biblical story with new details and differs in some places from the scriptural life of Job. References to women
and music constitute important accretions which seem to have pervaded medieval and music constitute important accretions which seem to have pervaded medieval
perceptions of Job. Job's wife becomes a supporter of the devil in the Testament, perceptions of Job. Job's wife becomes a supporter of the devil in the Testament,
unable to resist his lures. Music, on the other hand, plays an interesting role in stirring Job's household to loving God. The Testament thus contributes a perception of Job as a poetic biblical figure, following the tradition of David the psalmist and Solomon, writer of the Song of Songs.

Had the Book of Job circulated in this fashion only, one could doubt that it would have had sufficient exposure to guarantee its widespread late medieval popularity, not only within the clerical milieu, but also among the laity. The contextual setting of the liturgy, which drew on passages from this biblical book, may account for its popularity. I would like therefore to turn to the use of the Office of the Dead used in two liturgical contexts, the medieval funeral and the ceremony of enclosure for anchorites, in order to assess how those contexts precipitated Rolle's own interest in such a text and how they explain fifteenth-century interest in Super novem lectiones.

The ideal medieval funeral consisted of five main parts: Last Rites, procession from home to church, services at church (Office of the Dead, Requiem Mass and absolution), procession from church to cemetery and burial." Each part stressed the communal dimension of the event: death was perceived as departure from the community of the living to the community of the dead. Confession, communion and extreme unction took place at home; together they made up the Last Rites. However, depending on the wishes of the dying person, the Last Rites could be simplified to include only the Commendation of the soul. In any case, the viaticum, i.e. the administration of Holy Communion to the dying person, which was mentioned as early as the fourth and fifth centuries at Church councils, marked the beginning of the soul's journey from the community of the living to that of extreme unction, both for practical reasons the Eucharist just before the moment 
trends which emphasised more individual forms of piety in this period. In addition, new devotion to the Eucharist and intensified belief in the real presence of Christ required a more solemn moment and the assurance that the body of Christ would not be given to a corpse. Also, as only the parish priest was allowed to give the viaticum, his presence at the time of death could never be assured, and one would therefore call him in the early stages of the passing of the dying into the other world. ${ }^{3}$ The carrying of the host to the sick was sometimes solemnised in the form of a procession, of which tere are recorded cases already in the seventh and tenth of a process conth centuries. From the thirtenth century onwards, an indugence, set by the pope at one hundred days in 1389, was offered for those who followed the procession. Further evidence for the highly communal dimension of this event is attested by the extensive manuscript illuminations showing the community actively participating in the medieval funeral; these are found in Books of Hours meant to accompany material for the Office of the Dead. As an alternative to the Last Rites (if they could not be admingter no be a misto honis animae gathered the community around the dying and ritualised the momen of death as one during which the spirit of the dead was given back to the Lord (commendo). The community's commendamus for the departing soul was long enough to ensure that the soul had left the body. Once the mortuary ablutions had been performed, the corpse would be borne in procession to the place where it would be watched until inhumation. It is worth noting that the Office of the Dead, which was performed in the church, replaced in some instances the commendatio animo was peffor in the hurch, when the clergy left the family to take care of the corpse, hence resulting in the loss of sacramental value for the rituals taking place in the home. Moreover, the liturgy, which before the twelfth century celebrated the dead, afterwards encour aged a more general and affective meditation on death. The shift is of great importance to the emergence of meditative and personal writings on death in particular and concerns for the transitoriness of earthly life in general. So, while after the twelfth century and at the close of the medieval period it was common practice tive orisons, followed by the adoration and kissing of the crucifix (as witnessed in Julian of Norwich's Revelation of Love), it does not mean that prior funcral rites fell completely out of favour: practice differed from one area to another, from one parish to the next, with in some cases a blending of the old with the new.

The official and ritual recitation of the Office of the Dead from breviaries took place after the body had been placed in the church. As this liturgical ritual is of momentous importance for our understanding of a possible context for the writing of Rolle's Super lectiones mortuonum, a more detailed study of the arrangement of this office within a few English breviaries seems necessary. Only a few complete monastic breviaries survived the sixteenth-century Reformation. ${ }^{4}$ The breviary from Hyde Abbey, Winchester, extant in two manuscripts written around 1300 exemplifies Benedictine practices of the early fourteenth century. It attests to the early existence of an Office of the Dead in England, incorporating extracts from

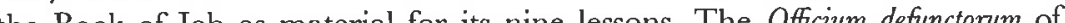
Hyde Abbey Breviary is extant in one manuscript only, Oxford, Bodleian Library
MS Gough Liturg. 8, with the Psalter and Canticles as companion pieces. It is arranged for recitation In primo nocturno, Ad matutinas and In laudibus. ${ }^{5}$ Psalms and antiphons precede a list of eleven prayers. ${ }^{6}$ Apart from the first prayer, which ask God to take care of the departing soul, the ten other prayers demand intercession and blessings for abbots, patrons and benefactors, and thus demonstrate the different uses made of this office within a monastic community. The orison for dead benefactors recommends their soul to God and asks on of spiritual benefits equivalent to the earthly ifts they grantel the of spiritual benefits equivalent to the earthly gifts they granted the monastery. The first section of matins includes Psalms 5, 6 and 7, with two interlacing antiphons, followed by the first lesson, from Job 7: 16-21. Lesson two includes Job 10: 1-7, followed by a response on the resurrection of Lazarus. The first section of matins concludes with lesson three, which offers Job 10: 8-12, followed by two short responses. The second part of matins, In secundo noctumo, introduces two shor (Job 13: 22-28) with Psalms 22, 24 and 26 and three antiphon Job 14: 1- 6 (les five) and Job 14: 13-16 (lesson six) conclude the second part. Job 14: 1-6 (lesson of the of the Book of Job appears throughout matins. Lesson seven (Job 17: 1-3, 11-15) and lesson eight (Job 19: 20-27) are made up almost exclusively of extracts from the biblical book. Lesson nine, which concludes matins, includes Job 10: 18-22, followed by responses and Psalms 119 and 141. Psalms 50, 64, 62, 66, 148, 149, 150, Psalm Benedictus, 129 and 141 , are read with appropriate respos antiphons for lauds. The daily recitation of the office contributed to a wide and detailed familiarity with $\mathrm{J} b$, both in mo material on the Offe of material on the Office of the Dead in the York breviary is accidental, and does not therefore attest to the absence of such liturgical ceremonies in the diocese. English secular liturgical practices for that office can be found, among other examples, in both the Hereford and Salisbury breviaries. The core of the office, i.e. the nine lessons from the Book of Job, appears to be unchanging from one use to the nine Changes occur in the range of prayers available for commemorations following vespers, yet antiphons and psalms for vespers, matins and lauds seem to be used
quite consistently.

The remaining two funeral services taking place in the church were the Requiem Mass and absolution. They were followed by the procession from church to cemetery, and by the burial itself. Dying well, that is at home, surrounded by the community of the living, and with the proper funeral rites, was of great concern to medieval people. The dying was fully aware that, once dead, he depended the goodwill of the living for their prayers to intercede on his belis in on alleviate his pain and time in pura alleviate his pain and time in purgatory. The community of the living thus had the upper hand in this aspect of the economy of salvation.

\section{Context two: anchoritic contexts}

The liturgy of death in general exercised a great influence on the liturgy which made up ceremonies of enclosure in medieval England. ${ }^{7}$ In the Pontifical of Magdalen College, dating from the twelfth century, the service for the enclosure ceremony shares some distinctive characteristics with those belonging to the death ritual: 
tapers; blessings with holy water and incense; antiphons and psalms drawn from for the dying: all of these are part and parcel of the liturgy of death. ${ }^{3}$ The transposition of those ritual discourses from the dead to the postulant anchorite pervades anchoritic writings, most notably in the dead-to-the world motif which echoes and feeds on the profound psychological impact of the enclosure ceremony. Further evidence for this transposition may be found in the Ordo includendi famulam Dei, seen in the Ponif al of Archbisop Baibridge of York. ${ }^{2}$ The ceremony, generally performed by the bishop, stresses from the onset the penitential character of the whole ceremony by requesting God's pardon for the sins of the assembled congregation. The bishop, prostrating himself before the altar, recites sixtcen psalms, including some of the so-called penitential psalms. The two following prayers address God and the Virgin Mary on behalf of the anchorite (tuam famulam) and beg for protection from temptations, as well as freedom from all crimes, to ensure (nill rejoice eternally that istam, Requiem aeternam', is a clear sign for the recitation of a Mass for the Dead at this particular moment of the ceremony. ${ }^{10}$ Following the reading of the Gospels, possibly John 6: 37-40, the postulant anchorite then makes her promise." Her garments are blessed, and a prayer stressing their symbolic significance, i.e. humility of the heart and contemp for the world, ensues. Three more prayers precede the blessing of the veil, asking Cod to by the bishop over the head of the anchorite, who is asked to prepare herself in her fight against the devil, the world and the flesh. One more instance of the transposition mentioned above appears in the number of psalms found both in the Officium mortuorum and the ceremony of enclosure. Of the twenty-one psalms found in the latter ceremony, five are shared with the Office of the Dead. ${ }^{12}$ Other psalms and antiphons drawi from the same office are sung during the procession leading to the reclusorium ${ }^{13}$

Johannes Busch, a German Augustinian provost from the first half of the fifteenth century, offers a unique account of the performance of a ceremony of enclosure in the Chronicon Windeshemence und Liber de Reformatione Monasteriorum. Most of the devotions which the anchorite will be required to perform in her new life are seminally present in the ceremony. As an example from the very late Middle Ages, it stands as unique testimony of enacted liturgical practice. The first part tests the postulant anchorite on three points: (1) her intention to live as an anchorite (2) her readiness to accept cagerness to fight the devil, the world and the flesh:

Sacerdos hic subiecta debet interrogare includendas: "Vis includi et solitarian vitam ducere propter deum et sic, quamdiu vixeris, permanere?' Respondeat: 'Volo.' Item dicat: 'Vis obediers esse episcopo tuo et nobis ex parte eius usque in finem vite tue?' Respondet: 'Volo.' Tunc dicat ei, quas molestias um quod hoc viriliter velit aggredi et contra mundum et carnem suam tamquam mundo mortua decertare. Et respondeat: Propter amorem dei et anime sue salutem orationibus bonorum confisa ad omnia premissa cum dei adiutorio est parata.

[The priest here must ask the enclosed one lying near: 'Do you want to be enclosed and lead the solitary life for (the love of God) and remain so as long as you live?' Let her reply: 'I do'. Then let him say: 'Do you want to be obedient to your bishop and to us as his deputy till the end of your life?' She answers: 'I do'. Then let him tell her which difficulties she wour life?' She endure and hat 'Then let to endure and that she would have to fight the devil, or whether she had deliberated well that she wanted to be assailed courageously and to strive against the world and her own flesh by being dead to the world. And let her answer that for the love of God and the salvation of her soul trusting in the prayers of the good people, she is, with the help of God, prepared for all those foresaid conditions. $]^{14}$

The paramount moment of the second part includes a mass of the Holy Spirit. After the Credo, the priest turns to the postulant anchorite and asks whether she wants to make her profession. He then hands to her the rule of St Augustine and asks her whether she is willing to live under this rule for the rest of her life. The reading of the profession follows. The gift of the cross betokens important aspects of her future life, already present in the words pronounced by the officiating priest:

Sequuntur letanie, post collectas 'Regnum mundi' cantatur. Post investitionem missa de Sancto spiritu cantatur. Post 'Credo' vertit se sacerdos ad eam dicens: 'Soror iam factura es professionem. Estis bene deliberata ad faciendam professionem, ad pugnandum contra carnem, mundum et dyabolum?' Et quanta districtione exigetur ab ea, quod profiteur, etiam ei proponat Postquam dedit consecnum, the dicens: "Accipe regum istam, quam proficin dicens: 'Accipe regulam istam, quam profiteri disponis. Vis secundum eam vivere in inclusorio usque ad mortem?' Dicit: 'Volo ita.' Tunc legat professionem suam; si nescit tunc legat eam dyaconus vel alia femina. Professione facta dicit sacerdos: 'Confirma hoc deus' etc. cum quinque collectis ad hoc assignatis. In fine missae commmunicat eam. Missa finita vertit se ad eam dicens tres collectas. Tunc dat ei crucem ulnis suis eam imponens et dicat: 'Accipe imaginem Crucifixi, cuius passionem et mortem in corde tuo sem de tuo semper

[Then the litanies follow and, after, the collect Regnum mundi was sung. A mass of the Holy Spirit was sung after the investiture. After Credo the pries turns towards her saying: 'Sister, soon you will have made your profession. Have you deliberated well about making it, fighting the flesh, the world and the devil?' And it is drawn out of her with such exactness that it may abo be clear to her what she is declaring to all. After she gives her agreement he hands over to her the rule of Saint Augustine, saying: 'Accept this rule, which 
you have arranged to declare. Do you wish to live according to it in seclusion till you die?' She answers: 'I do indeed'. Then she reads her profession; if she Wow to read then a deacon or another woman reads it. Once the profession is made the priest says: Confrma hoc deus etc. with five collects assigned to it. At the end of the mass he administers communion to her. Once mass is over he turns towards her saying three collects. Then he gives her the cross, placing it in her arms, and he says: 'Receive this image of the crucified one and take care to always keep his passion and death in your heart.']

The procession is also an important psychological moment. Dressed in white, the recluse, holding the cross, is led by the officiating priest and other attendant priests through the cemetery to her cell. The symbolic force of the cross is enhanced by the fact that the anchorite enters the cell with it and thus suggests strong metaphorical possibilities between the Passion and the life led into the anchoritic cell. The chanting of responses and psalms borrowed from the Office of the Dead is significant and demonstrates close similarities with funeral processions.

Post haec sacerdos incipit, 'Asperges' et ducit eam cum alio sacerdote per cemiterium cum eadem cruce, albis induti, cantantes responsorium 'Regnum mundi' et responsorium 'Accessit ad pedes Christi peccatrix'.

[After that the priest begins, Asperges and he leads her with another priest through the cemetery with the same cross, the two priests dressed in white, singing the responses Regnum mundi and Accessit ad pedes Christi peccatrix. $]^{16}$

The final moment of the ceremony takes place before the reclusorium, which is blessed with holy water and burning incense, thus echoing again the final ritual practice of blessing the corpse before its burial. The importance of the cross is again forcefully stressed. The recluse is then introduced into her cell and the door is shut behind her:

Tunc ducit eam in inclusorium cum cruce, quam secum tenebit in inclusorio usque ad finem vite sue in memoriam passionis Christi. Tunc sacerdos dicit: 'Dominus custodiat introitum tuum et taceat exitum tuum.' Respondeat chorus: 'Ex hoc, nunc et usque in seculum.' Qua in via ante clusam prostrata dicatur psalmus 'De Profundis' cum 'Requiem', ... Deinde quinque benedictionum orationibus et crucibus eam confirmet et benedicat. Deinde sacerdos benedicit inclusorium quinque longis orationibus.

Then he leads her into the reclusorium with the cross, which she will keep with her in the reclusorium till the end of her life in memory of Christ's passion. Then the priest says: 'May God protect your entrance and prevent your coming out.' Let the choir respond: 'From now, and for centuries onwards.' And as she is prostrate on her way, before the door, let the Psalm De profundis be said with Requiem, ... Then he confirms and blesses her with ive prayers of blessing and crossings. Then the priest blesses the reclusorium with five long prayers. $]^{17}$
Penitential elements and notions of earthly deprivation, present in both the Job story and the liturgy of death, form an equally important part of the anchoritic ceremony of enclosure. Evidence for the presence of the person of Job in the psyche of the audience reading anchoritic and eremitic writings is abundant. As the embodiment of patience, humility, perseverance, and determination in the belief of spiritual truth Job displays characteristics of inner strength, which in the the hallmarks of a good who sul o who succumbs to the devil, and leads a life of complete deprivation and hardship. Illness and disease are his most faithful companions. ${ }^{18} \mathrm{Job}$ is dead to the world and lives in expectation of the Last Judgment. In the De institutione inclusarum, Aelred of Rielvaux reminds his sister of the necessity of combating idleness by referring to Job 14: $2{ }^{19}$ The perseverance and strong will of Christina of Markyate, in her refusal to become betrothed to Burthred, evoke a proverb reminiscent of Job 19. 'Constant dripping wears away a stone'. Furthermore, the Ancen Wissob 14 strikingly large du strikingly large number of textual references to both Gregory's Moralia in $\mathcal{F}_{0} b$ and the Book of Job, as well as allusions to the character himself. Gregory's Moralia in $70 b$ states: 'If anyone is careless about the custody of her outward sight, she will become blind, through the just judgement of God, in her inner sight'. ".0 Gregory's sentence summarises the advice given by the Ancrene Wisse author on the custody of the senses, i.e. being blind to the outside world in order to open up the eyes of the spirit. Other quotations from Gregory's Moralia in Job deal wh the eyes tion, more specifially recognising on's own imperfection, more specifically recognising one's own imperfections, and counsel against boasting about one's achievements and being deceived by the devil into slothful acts. ${ }^{21}$ The Ancrene Wisse author appropriates and develops Gregory's misogynistic motif: women are easily overthrown and should therefore never be appointed as custodians of the soul. Furthermore, the Book of Job is cited fifteen times in Ancrene Wisse. ${ }^{22} \mathrm{Job}$ is a model for the anchoress in many respects: as guardian again the eyes (Job 31: 1), as a persevering spiritual seeker (Job 3:21) and as a secret performer of good deeds. Views on the relationship between the flesh and the soul rely on Job 28: 25. Moreover, Job is pervasively present in part four of Ancrene Wisse, 'On Temptations'. The author warns his anchoresses against presumptuou assumptions about their elevated spiritual status and its consequent absence of temptation, in opposition to the constancy of the character Job in Job 23. 10 . Reference is made to sickness sent by God and its purifying powers on the which a list is devised from the various medieval reporys on Job's ow expent, of with illness. The classification of the outer and ins with illness. The classification of the outer and inner temptations into four kind rests on four citations from Job: Job 14: 19, 41: 23, 30: 13, and 30: 14. Elsewhere Job 41: 25 serves to demonstrate holy people's nced for humility to escape the attacks of the devil. This is the trick used by the Lord Himself to combat the wrestler of hell. The idea of life as a fight is sustained in Part Six, On Penance, with Job 7: 1. Ascetic practices fall within this scheme and here again Job is recalled:

'Folc tolaimet ant totoren' wið strong liflade ant wið heard he cleopeð 'folc [fearlic]', for pe feond is of swucche offruht ant offearet. For-pi pet Iob wes pullich, he meande him ant seide, Pellem pro pelle et universa et cetera, bet is, 'He 
wule 3eouen fel for fel', be alde for be neowe; as bah he seide, 'Ne geineð me nawt to asailin him; he is of pet totore folc, he tereð his alde curtel, an torendeð pe alde pilche of his deadliche fel for pe fel undeadlich pet is pe neowe ariste schal schine seoueald brihtre pen be sunne.'

A people mutilated and torn by their severe way of life and by hardship: he calls them a fearsome people because the devil is frightened and fearful of such people. Because Job was like this the devil lamented and said to him,

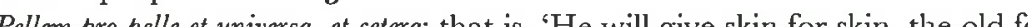
the new' as though he said, 'I will gain nothing by assailing him. He is one of those mutilated people; he tears his dress, and rends apart the old garment of his mortal skin.' For the skin which is in the new resurrection will shine seven times brighter than the sun is immortal. $]^{2.5}$

A sound spirit must be preferred to a healthy body (see Job 39: 25). The Ancrene dis a bu up of good works and faithful belief. At a more practical level, Job is used again by the author in his attempt at injecting new layers of meaning into the image of the reclusorium. Firstly, a bird analogy is cleverly applied to describe the inner workings of the anchoress's mind. The nest imagery first defines the general frame of mind which is suitable for an anchorite:

For- bi beo flesches pine efter euchanes euene. Pat nest beo heard wib uten, ant softe ant swete be heorte wiðinnen. Beo be beoð of bitter oðer of heard heorte ant nesche to hare flesch, ha makieð frommard hare nest, softe wiðuten ant porni wiðinnen.

[Thus the mortification of the flesh should be according to each one's capacity. That nest should be harsh on the outside, and soft and sweet the heart within. Those who are bitter or hard-hearted and are soft to their flesh make their nests backward: soft outside and thorny within.] ${ }^{2}$

The nest image refers also to the reclusorium. Job is the authority called upon to support this image:

Iob cleopeð nest be ancre hus, ant seið as he were ancre, In nidulo meo moriar, pet is, 'Ich chulle deien i mi nest, beon ase dead prin (for pet is ancres rihte), ant wunien aðet deað brin, bat Ich nulle neauer slakien, hwil be sawle is i pe buc, to drehen heard wiðuten, alswa as nest is, ant softe beo wiðinnen.'

Job calls the anchorhouse a nest, and says, as though he were an anchorite,
Jo to drehen heard widuten, alswa as nest is, ant softe beo widinnen.' In nidulo meo moriar - that is, 'I shall die in my nest, be in it as though dead. For that is proper for an anchorite, and to live in it until death: 'So that I will never cease while the soul is in the body to suffer harshness outwardly, as a nest is harsh, and to be soft within.']

The development of such a strong association between Job and the anchoritic mode of life builds upon the liturgical tradition, which allowed creative authors to develop further images intimately linked with one another in formal liturgica contexts. The anchorhold's analogy with the grave is more evidence of the influence of the liturgy for the dead on the anchoritic life:
ents

Hoker ant hofles ping is pet a smiret ancre - ant ancre biburiet, for hwet is ancre-hus bute hire burinesse? - schal beo greattre ibollen, leafdiluker leote of, pen a leafdi of hames.

It is a contemptible and unreasonable thing that an anointed anchoress, and an anchoress buried - for what is an anchorhouse but her grave? - wishe to be more graciously regarded than the lady of a house. $]^{20}$

Allusions to extreme unction and the Requiem Mass are instrumental in hammering important spiritual points into the psyche of the three anchoresses in Ancrene Wisse. The demand for the recitation of Psalms 114:9 and 5:9, which respectively open vespers and matins of the Office of the Dead, as part of their private devotions, is part of the same strategy, reinforcing the dead-to-the-world motif which characterizes the anchoritic life. ${ }^{27}$ It was common in the eleventh motif which characterizes the anchoritic life. ${ }^{27}$ It was common in the eleventh
and twelfth centuries for the recluse to be buried in her cell and the practice of the Syon nuns to visit an open grave within their enclosure between Terce and Sext to meditate upon their mortality may be an offshoot of this tradition..$^{28}$ The following passage in Ancrene Wisse remains ambivalent as to whether it should be read literally or metaphorically:

ha schulden schrapien euche dei pe eorðe up of hare put pet ha schulien roten in. Godd hit wat, pet put Deð muche god moni ancre; for as Salomon seið, Memorare nouissima tua et in eternum non peccabis. Peo pe haueð eauer hire deað as biuoren hire ehnen (pet te put muneged)

[They should be scraping the earth up every day out of the pit they must rot in! God knows that this pit does much good to an anchoress - for as Solomon says: Memorare novissima tua et in eternum non peccabis. [Remember your last hour and you will never sin] (Ecclesiastes 7: 40). She who always has her death as though before her eyes remembers that pit.. $]^{2 \cdot}$

Job's importance in this strategy is further evidenced by the demand for the recitation of three different lessons each night, and the recitation of the nine lessons in some special cases: 'For the anniversary of your dearest friends say all ' recitation of the lessons of the Office of the Dead started on the day the anchoresses made their vows. It would end only on the day of their physical burial.

\section{Context three: clerics, lay readers and the \\ anchoritic mode}

Super novem lectiones was probably written just before Emendatio vitae, at a time when Rolle was already engaged in the dissemination of his spiritual precepts to various communities, among them the nunnery of Hampole, and individuals such as the 
anchorite Margaret Kirkby, for whom The Form of Living and The English Psalter were written. As the eremitic mode of life was much less prescriptive than the anchoritic one, it is very likely that Rolle turned to, and aligned himself with, anchoritic models in order to enhance the credibility of his own way of life. As Eddie Jones has clearly demonstrated, Rolle indeed stands as an oddity when compared to other fourteenth-century hermits. Indeed, evidence suggests that hermits contemporary to Rolle were essentially devoted to road mending and bridge keeping, with little evide for literacy and spiritual claims or competence, and with no proper religious ceremony of investiture to lend credibility to their position. Rolle's support of female anchorites may have served as a means of strengthening his own eremitic status in order to align himself with the anchoritic paradigm. I contend that Rolle's awareness of the pre-eminence of the performance of the Office of the Dead by anchorites, along with his own desire to be associated with anchoritic culture, prompted, at least in part, the writing of the commentary Super novem lectiones. Tha bing sid, gentage period, should obviously be considered as another strong incentive for the writing of such a commentary. The character Williams in Shakespeare's Henry V (Act 4, Scene 1, 123-33) offers a moving testimony to how the art of dying well pervaded fifteenth-century mentality:

But if the cause be not good the king himself hath a heavy reckoning to make, 作 at the latter day and cry all 'We died at such a place', some swearing, some crying for a surgeon, some upon their wives left poor behind them, some upon the debts they owe, some upon their children rawly left. I am afeard there are few die well that die in a battle, for how can they charitably dispose of anything when blood is their argument? Now, if these men do not die well, it will be a black matter for the king that led them to it, who to disobey were against all proportion of subjection. ${ }^{31}$

The emergence of Ars moriendi treatises in the fifteenth century, together with The emergence of Ars moriendi treatises in the Book of the Craft of Dying, testifies as well to this general interest in being provided with instructions about how to comfort the dying. ${ }^{32}$ Super novem lectiones shows at least once a similar concern for the fate of the dead:

Debemus, fratres, orare pro animabus defunctorum, ut a penis liberentur, cogitantes quod libenter \& gaudenter amplecteremur aliorum auxilium si in eisdem tormentis essemus. Et uere nos nescimus quam cito hinc rapiemur et cum discesserimus si ad grauiora tormenta perducamur.

WWe must, brothers, pray for the souls of the dead, to free them from their affliction, thinking that we would gladly and joyfully embrace the help of others if we were in those same torments. And indeed we do not know how others if we were in the we shall be led towards more serious torments. $]^{33}$
If this passage from lesson eight shares similar, but passing, concerns with the Ars moriendi treatises, the overall work does not otherwise implement provision of instructions to those comforting the dying.

In this final part I propose, first, a brief textual analysis of Super novem lectiones, highlighting its most significant themes and strategies. Second, I offer an assessment of the fifteenth-century readership of this treatise, looking at the ways by which Rolle's association with anch provides partial explanation for its lasting popularity in the fifteenth century.

Considered in the larger context of Rolle's entire corpus, Super novem lectiones is one of the first of the Rollean treatises to move away from essentially lofty and personal mystical outpourings. Instead, it considers more down-to-earth themes accessible to a less experienced audience. The treatise borrows from Rolle's previous pieces and claims also to be written with a devotional aim in mind, as were his two Passion meditations. So, although there is a sense of continuty betwe works, the way in which Rolle gives up the role of the bride of the Song of Songs for that of the penitent Job alters dramatically the nature of this piece and hence its possible readership. ${ }^{34} \mathrm{Job}$ becomes the model with which Rolle and his readership can reform their own selves:

Beatus uero Iob, a possessionibus \& a diuiciis spoliatus, filius orbatus, ab uxore improperatus, ab amicis calumpniatus, morbo graui percussus \& nudus in sterquilinio sedens maximeque tribulatus, aperte ad Deum clamorem dirigit \& in tanta miseria positus, cum desiderio dicit: Parce michi domine, nichil enim

$\&$ in tanta
sunt dies mei.

[Truly, blessed be Job, deprived of his possessions and wealth, deprived of his son, insulted by his wife, calumniated by friends, hit by serious illness and sitting naked on the dung-heap and greatly troubled, he openly directs his cry towards God and, placed in such misery, says with longing: Parce mihi domine, nichil enim sunt dies mei.] ${ }^{33}$

Rolle defines the character of Job in terms of a heroic solitary fighter against the world, the flesh and the devil. This imagery is of course a hallmark of anchoritic literature and Rolle's contact with anchoresses may have triggered his interest in making it an important element of this treatise. The perfection of the solitary life remains Rolle's battle horse, but it is now depicted with a much closer look at the even ascetical qualities which characterises it. Together with patience and humility, they are hallmarks of the treatise. ${ }^{36}$ To the question found in Job 7: 17 (Quid est homo?), Rolle provides a definition modelled on Job as God's good servant:

Itaque: Quid est homo quia magnificas eum? id est, qualis \& quantus est homo quem tu magnificas? Est autem mundus, iustus, pius, castus, sobrius, humilis, mansuetus, paciens, misericors, sanctus, sincerus in mente, feruens in tuo amore, caritate repletus, omnium virtutum genere insignitus.

[So: Quid est homo quia magnificas eum?, that is, who and how great is the man 
that you praise? Among others, he is pure, just, pious, chaste, sober, humble, gentle, patient, enduring, merciful, holy, sincere in spirit, fervent in your love, filled with charity, marked by all kinds of virtues. $]^{37}$

Rolle constructs a model fashioned by moral rather than spiritual qualities. Meditations on the Passion, so conspicuous a feature in anchoritic spirituality, borrowed and adapted for private lay use in the fifteenth century, appear in the form of meditative ruminatio in Super novem lectiones, with particular insistence on the aftermath of the Passion:

Sic inter mala positus respiciat in suum adiutoreum, consideret Christum pro suis excessibus in cruce pendentem, \& medullitus memorans sanguinem Saluatoris, mortem redimentis, dolorem morientis, uictoriam resurgentis, gloriam ascendentis, iusticiam ad iudicium uenientis; dicat letus cum Apostolo: Michi absit gloriari, nisi in cruce domini nostri Ihesu Christi: per quem michi mundus crucifixus est, \& ego mundo.

[So, placed amidst evil he looks for his helper, he considers Christ hanging on the cross for his moral failings, remembering deeply in his heart the blood of the Saviour, the death of the redeemed one, the pain of the dying one, the victory of the resurrected one, the glory of the ascending one, the justice of the one to come to judgment; joyful, he says with the apostle: far be it from me cross of our lord Jesus Christ: through whom, the world is crucified to me, and I to the world. $]^{38}$

Repentance and recognition of one's own sins feature among Rolle's most personal outpourings. ${ }^{99}$ We are quite far here from Rolle's own expostulations which made a case of him as a member of the Church Triumphant. Here instead, his exhortations for penitence and his repetitive perorations on the transitoriness of this earthly life echo those of Job:

Sed bonum est, fratres, humiles esse, miseriam nostram recogitare, dicentes cum beato Iob: In puluerem reduces me. Necesse est michi mori \& in pulverem reduci, quia omnes morimur \& quasi aqua delabimur in terram. Sed o bone domine cum morior \& reducor, in cinerem animam meam digneris accipere et tecum in eterna gloria collocare;

But it is good, brothers, to be humble, to recognize our misery, saying with blessed Job: 'In puluerem reduces me.' It is necessary for me to die and to be with blessed Job: 'In puluerem reduces me.' It is necessary for me to die and to be
reduced to dust, because we all die E̊ quasi aqua delabimur in terram. But $\mathrm{O}$ good lord after I die and I am brought back, you will deem worthy to accept my soul in ash and to establish it with you in eternal glory. $]^{10}$

Faced with the inexorableness of his own human frailty and life's fleetingness, Rolle finds comfort by devising in his mind a reassuring image, that of the fixity of milk when turned by curdling into cheese. Metaphorically interpreted, it stands for spiritual love which, once curdled, i.e. transformed from carnal love into its present spiritual state, is fixed, thus no longer mutable. Job 10: 8-12 facilitated the development of this image, and shows God to be in control of this chemical process: Et sicum caseum me coagulasti ${ }^{41}$ When emphasis is put on God's relationic. with the soul, the Song of Songs imagery serves as an anat on God's relationship some of the verses of the Book of Job, setting the text's allusions to the bretain of cornerstone on which metap beatific vision, whe forstructed. Reference to the beatific vision, the face-to-face, used with extreme caution by Rolle throughour his corpus, demonstrates, despite the penitential tone of this treatise, continuity in his spiritual aspirations in the context of a generally sober, more ascetic, form of spirituality.

The popularity of Super novem lectiones is symptomatic of the spread of private devotional practices which marked the fifteenth century. I argue that this work sheds light on the ways in which those devotional practices involved the participation of several components for its effective spread. The first and second sections of this chapter show clearly the complexity of overlapping influences for the circulation of religious practices. Both the funeral ritual and its use within anchoritic culture played a part in the composition of the piece. I would like to stress, however, that its fifteenth-century popularity among the secular clergy grewes, of the fact that it projects a form of spirituality concon anchorites and which the scoular clergy and its audies imitation ${ }^{12}$. imitation. ${ }^{12}$ Jonathan Hughes's attempt at describing the impact of eremitic spirituality upon lay practice in fifteenth-century Yorkshire offers interesting evidence as to the role played by Super novem lectiones in this grander scheme: several members of the secular clergy of York Minster owned copies of this work. ${ }^{+3}$ Hughes links York clerical ownership to an increase of services for the dead in the it seems this view does not take sufficiently into consideration work, which is for individual meditative consupto rate

Manuscript ownership of Super notve tectict use."th Manuscript ownership of Super novem lectiones points to the clerical milieu as a significant readership. ${ }^{45}$ However, recent studies have shown that circulation of books between ecclesiastical institutions and lay individuals contributed to the ise of networks of devotional readers, male and female. This Latin treatise may not have had the same kind of impact as other vernacular devotional work my have had on lay readers. However, ownership of Latin texts by lay reate may not have been just a way of displaying one's gentility ${ }^{46} \mathrm{After}$ all, there is ens evidence to show that having a d a nentere is enough evidence to show that having a book read or/and translated to the lay reader was still common practice in the late medieval period. When Oxford, MS Laud Misc. 528 passed from the hands of the Province-General of the English Franciscans into those of a layman and his wife in the fifteenth century, it possibly marked moment in a series of exchanges between a Franciscan of high stanting with lay individuals interested in the reading of some of Rolle's most signifis wo Several other manuscripts were owned by me no clear picture, apart from that of diversityonastic institutions or clerics, so tha no clear picture, apart from that of diversity of readership, emerges from a succinct overview of manuscript ownership. Returning now to the Yorkshire milieu, on finds a religious context which was highly influenced by anchoritic practices, from the clerical sphere to other levels of secular society."13 The aristocracy, the gentry, 
merchants and clergy supported and found a personal interest in the anchoritic way of life, ${ }^{49}$ If the thirteenth century was an anchoritic golden age for the whole of England, the fourteenth century was even more so for the diocese of York, which had an anchoritic population of fifty-eight, by far the largest in England at any time, against (only) fourteen in the thirteenth (fourth highest number after Northamptonshire, twenty-one: Oxfordshire and Kent, fifteen). ${ }^{50}$ Super novem lectiones anplons would have appealed to those who enacted the cerence recluses, provided for their sustenance and regarded the anchoritic pattern as an exemplary model, and looked into writings which offered a spiritual reference inspired by that mode of life. Richard Russell, a parishioner of St John's, Hungate, i one example of anchoritic interest among fifteenth-century Yorkshire's merchan classes. He provided in his will of 1435 large grants to the anchoresses at Walmgate and All Saints, North Street, and to others at St Helen's, Fishergate..$^{52} \mathrm{He}$ gate all St was also he own of Richard Tolleston, chaplain of York. In her studies of medieval wills in several English dioceses, Ann K. Warren points out that among twenty-five wills of group of Yorkshire merchants who lived between the mid-fourteenth and the midfifteenth centuries, thirteen left bequests to anchorites. ${ }^{51}$ She demonstrates further the involvement of all layers of English society with anchoritic behaviour, pointing to the importance of early royal patronage in boosting such broad support.

If one considers the Yorkshire area, the Scrope family is a good case in poin ff one consders the Yor wire are for our understanding of the role played by religious anchoritic culture within the networks which made possible the transmission of religious practice between monastic, clerical and lay milieus..$^{56}$ Several members of the Scrope family were staunch supporters of anchorites and hermits. Both Stephen Scrope, second Lor of Masham, and his son Henry, supported a recluse called Robert of Beverley in the early fifteenth century. Henry, who became the third Lord Scrope of Masham in 1405 , made bequests in his will of 1415 to each anchorite and anchoress living in the vicinities and cities of York and London, as well as making provision for seventeen anchorites from the diocese of York and one hermit. That commitment towards anchorites was continued by his successor, his brother John, fourth Lord Scrope of Masham..$^{57}$ According to Moyes, the Scrope family acted as an important link between the secular clergy of York and the Bridgettine house of Syon. The wills of the Scrope family additionally indicate an interest on their part

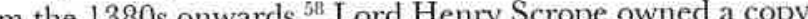
in the cult of Rolle from of the Fudica me Deus. Richard Scrope of Masham, Archbishop of York between 1398-1405, had an impact on the spread of Rolle's writings among the Arundel household, and he also was responsible for the compilation at Lichfield during his episcopate of Rolle's Ego Dormio, The Commandment, The Form of Living and the Incendium Amoris with other Northern works such as the Prick of Conscience and John of Howden's Philomela.5' John Newton, a close friend of Richard Scrope's from at least 1376, and one of the clerics of York Minster during Scrope's time as at lest 1376, and one of the cleries archbishop, was one of the owners of Super novem lectiones. . $^{\circ}$ Althought this account is far from exhaustive in its description of the direct involvement by the Scrope family in the support of anchorites and its interest in Rolle, it allows for an under- standing of the ways in which the Scrope family literally pushed Rolle's work into the precincts of York Minster and some monastic institutions. Super noven lectiones, as one of the works which made its way into the Minster, represents bes this double interest which seems to have appealed to the Scrope family and many other pious readers, i.e. a type of devotion based on an anchoritic form of spirituality with which Rolle made a point of aligning himself. No other work by Rolle insists so intensely on penitential spirituality, a feature No choritic mode of life in general. ${ }^{61}$ The interest in Rolle and his works by an educated clergy and ecclesiastical officials in fifteenthcentury York stems from the perception of him and his writings as a mouthpiece for anchoritic behaviour.

\section{Conclusion}

Super novem lectiones does not offer material for preparation of one's own death, no does it provide guidance to those attending the dying. ${ }^{63}$ Also, the voice of Job in that treatise does not become, as in the funeral performance of the Office of the Dead, the voice of the dead man crying for help. ${ }^{6 t}$ Instead, as in the anchoritic context of the ceremony of enclosure, the 'I' of the reading is that of the one dead to the world, but not yet in need of prayers to get out of purgatory and into heaven as quickly as possible. ${ }^{5}$ The voice of Job in the ceremony of enclow Super novem lectiones is one that, itself in a self-reflexive penite sate itself in a self-reflexive penitential mode, with an inward focus, but nevertheles aware of its own privileged position with regard to the large Christian community for which it voices prayers and meditations. Thus, the function of the biblical verses from the Book of Job in both contexts is a complete reversal of that of the Office of the Dead in the funeral ritual. The way in which the performance of the 'T' voice in those contexts empowers the performer has as yet been insufficiently studied, Sustained interest in the anchoric voction, and Rolle's own followig of its strict and well-regulated mode of life, which Super novem lection composition of Super novem lectiones with an interest shown by several layers of late medieval society, were fashioned to some extent by the appropriation of Job's persona and voice as haped in the multiple medieval cultural and literary contexts in which it circulated.

\section{Notes}

1 My research on this work takes into account the new chronology of the Rolle corpus CUP, 1991, pp. 273-94; it also owes much to the pioneering of Authority, Cambridge: Moyes, Richard Rolle's Expositio suffer novem lectiones moortuonum. An Introduction tion toccards a Critical Edition, Salzburg Studies in English Literature 92.12 Sontribu1988.

2 The following works have been used for this summary of the medieval funeral: $T$. Maertens and L. Heuschen, 'Doctrine et pastorale de la liturgie de la mort', Pavoise
et liturgie 5, 1956, 317-37; 6, 1956, 427-48; 1, 1957, 4-22; 3, 1957, 202-29; Ror 
Wieck, 'The Death Desired: Books of Hours and the Medieval Funeral', in Edelgard E. DuBruck and Barbara I. Gusick (eds) Death and Dying in the Middle Ages, New York: Peter Lang, 1999, pp. 431-76; Geoffrey Rowell, The Lituryy of Clinstian Burial: An Intro59, London, 1977 (esp. pp. 57-73); Edmund Bishop. 'On the Origin of the Prymer', 59, London, 1977 (esp. pp. 57-73); Edmund Bishop, 'On it

3 The practice of the viaticum is closely associated with the celebration of the mass, and it is from the offering of the viaticum to the sick that the mass for the sick emerged as a separate liturgical practice.

4 See J.B.L. Tolhurst (ed.), The Monastic Breviay of Hyde Abbey, Wünchester; MSS. Rawtinson Liturg. e.1*, and Gought Litury. 8, in the Bodleian Library, Oxfort, Henry Bradshaw Society 69, London: Harrison and Sons, 1932. Tolhurst lists 5 breviaries: (1) British Library Harleian MS. 4664, from Coldingham Priory (written c. 1270); (2) Cambridge University Library Ii 4.20, from the Cathedral Priory of Ely (written c. 1275); (3) Library of J. Meade Falkner, Esq., Durham, from Muchelney Abbey, Somerset (written c.1280, (4) Oxford, Bodleian Library MS Rawlinson Liturg. e.l and Gough Liturg. 8, from Hyde Abbey, Winchester (inten o. 1300), (5) Collhuge, The from Battle Abbey, Sussex (written c. 1500); see Tolhurst, op. cit. (1932), pp. v-vi.

5 See J.B.L. Tollow London: Harrison and Sons, 1934, fols G. 68v-70v. $14,119,120,129,137$ and the "evang

rical' canticle Magnificat (Luke 1: $46-55$

7 For a comparative study of English and German ceremonies of enclosure, sec Otmar Doerr, Das Instifut des Inchusen in Suddentseilland, Beiträge zur Geschichte des Alten Mönchtums und des Benediktineordens 18, Münster in Westf., 1934 (see esp. pp. 42-52). See also R.M. Clay, The Hermits and Anchorites of England, London, 1914; see esp. Appendix A, p. 192, for a translation of an Office for the Enclosing of Anchorites, according to the Use of Sarum; mention is made of the ceremony of enclosure in Ann K. Warren, 'The Nun as Anchoress: England 1100-1500', in John A. Nichols and Lillian T. Shank (eds, Distant Echoes: Mediezal Religious Women 1, Gistercian Studies Series 71, Kalamazoo M1 Cistercian Publications, 1984, pp. 197-212; see also Patriciaj.F. Rosol, The Anchores in the Twelfth and Thirteenth Centuries', in Lillian T. Shank and John A. Nichols (eds), Publications, 1987, pp. 123-44.

8 See Warren, op. cit., pp. 97-8.

See William George Henderson (ed.), Liber pontificalis Christophori Bainbridge, archiepiscoph Eboracensis, Publications of the Surtees Society 61, Durham: Andrews \& Co., 1875, pp. $81-6$.

11 The rubric in the Missale ad usum insigmis ecclesine eboracensis reads: 'Pro famulo vel famula dicitur hoc evangelium'; see W.G. Henderson (ed.), Missale ad usum insignis

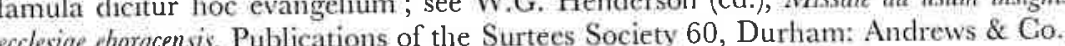
1874 , p. 184.

12 Psalm 6, Domine, ne in furore, is the second psalm of matins in the officium morthorum, Psaln 40 , Beatus qui intellivit, is the second psalm of the third nocturn of matins; Psalm 50, Miser, is the first psalm of lauds; Psalm 102: 1-5, Benedic, is the sixth psalm of lauds; Psalm 129 is the fourth psalm of vespers: Psalm Misere mei, Deus, is the first psalm of lauds.

13 See W.G. Henderson (ed.), Manuale at processionale ad usum minsgnis ectelesiate eboracensis Publications of the Surtees Society 63, Durham: Andrews \& Co., 1874; see also Jan Kuhlmann Frogley, 'A Processional of the York Use: An Edition of Bodleian Library MS E. Musaeo 126 (3612), with a Description, Dating and History of the Manuscript, unpublished thesis, University of Oxford, 1987; there is unfortunately no informa on processions conducted during ceremonies of enclosure in those processional.
4 See K Grube (ed) D Ges Angustineryroptstes Johannes Busch Chromion Hit de reformatione, Geschichtsquellen d. Provinz Sachsen 19, Halle, 1886, pp. 657; see also 15 Ibid., pp. $657-8$.

16 Ibid., p. 658

17 Ibid.

18 See Clay, op. cit., p. 124

9 See Aelred de Rievaulx, La Vie de rechuse, La Prière pastorale, ed. Charles Dumont, Sources Chrétiennes 76, Paris: Cerf, 1961, pp. 65-145.

20 Moralia in Job, Lib. xxi, cap. vii (PL 76, col. 197); quoted in M.B. Salu (trans.) The Ancren Rivule (the Corpus ms.: Ancrene Wisse), London: Burns \& Oates, 1955, p. 40

21 Ibid., pp. 65, 103, 121

22 Unless indicated otherwise, translations are from Anne Savage and Nicholas Watson (trans.), Anctloritic Spirtuality: Ancrene Wisse and Associated Works, The Classics of Wester 23 Bella Millet (ew York: The Paulist Press, 1991 (pp. 436-7).

Bella Millet (ed.), Ancrene Wisse: A Corrected Edition of the Text in Cambridge, Corphus Christ College, MS 402, with Variants from Other Mamscripts, EETS, o.s. 325, 2005, p. 137.; see also Savage and Watson, op.cit., p. 181

24 Millett, op. cit., p. 53; see also Savage and Watson, op. cit., p. 98

25 Millett, op. cit, p. 53; see also Savage and Watson, op. cit., p. 98

26 Millett, op. cit., p. 43; see also Savage and Watson, op. cit., p. 88

27 See Savage and Watson, op. cit., pp. 55-6.

sive Ianguae', in Liz Hexte Some Reflections on Wombs and Tombs and IncluSive Language', in Liz Herbert McAvoy and Mari Hughes-Edwards (eds), Anchorites, Culture in the Middle Ares, Cardiff: University of Wales Press, 2005, Religion and also Vincent Gillespie's chapter in this volume, 1. 136-66. Pres, 205 , pp. 2

; see also Savage and Watson, op. cit., p. 91-2; see also Clay, op. cit., p. 114 .

31 Wille and Watson, op. cit., p. 56

Wham Shakespeare, King Henty V, Andrew Gurr (ed.), The New Cambridge Shakespeare, Cambridge: CUP, 1992, pp. 154-5.

in DuBruck and Gusick, op. cit., pp. $379-499$

34 See Watson, op. cit., pp. 199-200; for a study of Rolle as biblical commentator, see J.P.H. Clark, 'Richard Rolle as Biblical Commentator', Dowenside Review 104, no. 356 1986, 165-213; for a treatment of Stuper notem lectiones, see esp. pp. 174-5, 178-83;

36 Moyes, op. cit., vol. 2, pp. 126-7.

According to some manuscript annotations, Rolle received a vision in 1343 at whether this vision ming the hears; one is left wondering material and a discus of Hope Emily Allen, Whiting or patience; see

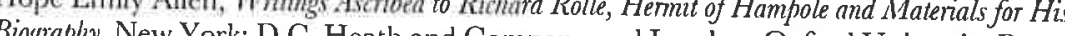
1927, pp. 27, 228; 37 Moyes, op cit vol. 2, p. 132

38 Ibid., p. 136.

39 Ibid, p. 146.

40 Ibid., pp. 182-3.

41 Ibid., p. 183

42 For a study of the religious background in Yorkshire in the fourteenth and fifteenth centuries and the special importance of Rolle, see Jonathan Hurhes, Pastors and Visinth aries: Religion and Secular Life in Late Medieval Morkshive, Woodbrige: Boydell Press, 1988 
Some of the material in this book must be treated with caution; for a critique of the

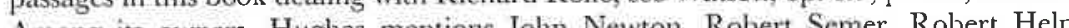
43 Among is aillam Ga, Bichard Drax, Willian Duffield and Thomas Pyncheck. Hugles, op. cit., p. 269.

44 Annie Sutherland offered a similar argument for the use of Rolle's English Psalter at the ESSE 7 Conference in Zaragoza, 8 September 2004.

4 For a list of manuscripts, their provenance and information of early ownership, see Moyes, op. cit., pp. 1-121.

46 Andrew Taylor, 'Authors, Scribes, Patrons and Books', in Jocelyn Wogan-Browne, Nicholas Watson, Andrew Taylor and Ruth Evans (eds), The Idea of the Vemacular An Anthology of Middle English Literany Theory 1280-1520, Exeter and University Par PA: University of Exeter Press and Penn State University Press, 1999, pp. 3.53-65.

47 The manuscript contains the following items: Emendation vithe, Judica me Deus, Oleun effisum nomen thum, Expositio super norem lectiones, and Incendim amoris. See Moyes, op. cit, vol. 2, pp. 16-17,

48 See also M.G.A. Vale, 'Piety, Charity and Literacy among the Yorkshire Gentry, 1370 1480', Borthwick Papers 50, 1976, 1-32; see also Vincent Gillespic, 'Vernacular Books of Religion', in Jeremy Griffiths and Derek Pearsall (eds), Book Production and Publistung Britain $1375-1475$, Cambric CUP, 1989, pp. 317-4t.

Tor a study or he ownership of Super nozem lectiones, see Moyes, op. cit., vol. 1, pp. 75-90; erchants' responses to the anchoritic life, see Warren, op. cit. pp. $247-55$.

51 centre of anchorite-related behaviour in the city of York; see also Hughes, op. cit. pp. $197-208$

52 Warren, op. cit., p. 245.

53 See Moyes, op. cit., p. 76 , note 42

54 Warren, op. cit., p. 247

55 Ibid., p. 281

p. cit., pp. 68-9, 87-8.

57 Ibid., p. 68.

58 See Moyes, op. cit., vol, 1, p. 82

59 See Hughes, op. cit., p. 203.

60 Ibid., p. 204, and Moyes, op. cit., vol. 1, p. 82.

61 See Moys, ap. di, vol. 1, p. 88: 'The adoption and use of these penitential teachings in the Expositio as useful for the instruction of the contemplative, by some medieval readers and scribes, is suggested by the presence in some MSS of more specialized texts such a

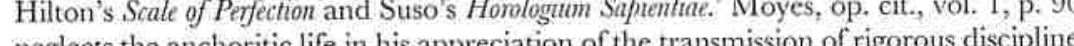
(a) See Moyes, op cit vol. 2 , p. 76

63 That is what the Ars moriendi treatise explicitly does; see Duclow, op. cit., p. 380.

64 See Wieck, op. cit, p. 433

65 Ibid., p. 432

\section{Issues of linguistic categorisation in the evolution of written Middle English}

Feremy F. Smith

Paleography has often been scen - with justification - as a distinct academic discipline. However, in common with many of the essays in this volume, this chapter derives its orientation from an interdisciplinary perspective; it is a modest attempt to demonstrate the articulation between paleography and other forms of linguistic enquiry. The illustrations are drawn from Middle English texts, but it is hoped that the discussion has broader implications.

\section{The relationship between speech and writing}

In recent years, many scholars from different perspectives have insisted on both the distinctions and the connections between the written and spoken modes of language. Such distinctions and connections are to be found most obviously at the level of transmission, i.e. where grammar and lexicon are passed from one language-user to another, either through speech or writing. The most obvious distinction may be expressed at its crudest as follows: one mode is expressed by means of the vocal tract, another by means of marks made on materia such paper, stone, wood, etc. (I leave out of account here 'body-language', e.g. handgestures.) And of course there are differences in the level of formality prototypical of the two modes, although there are gradations of formality in both. Such gradations have recently been extended, in the written mode, by habits developed
tions tions have recently been extended, in the written mode, by habits developed
in the use of e-mail and 'texting'. However, there is also an obvious connecin the use of e-mail and 'texting. However, there is also an obvious connection: both speech and writing transmit what is essentially the same lexicon and grammar.

Reflection on the relationship between the two modes is of course hardly new. In the West, classical and medieval grammarians were well aware of the relationship between the two modes, and developed theoretical frameworks to describe them. Authorities such as Donatus and Priscian adopted the 'doctrine of littera', which was developed to correlate speech with alphabetic writing-systems of the kind used for Greek or Latin. This doctrine distinguished between nomen ('name (of the letter)'), potestas ('power' = 'sound-value'), fimura ('representation' = 'writte symbol'), with the term littera ('letter') as a superordinate classificatory term."

This terminology still has considerable value in the discussion of medieval systems, as Benskin and others have shown. It makes clear the relationship between 